\title{
REAKSI PASAR MODAL TERHADAP PANDEMI COVID-19 DI INDONESIA
}

Rosa Novilia*, Yuliansyah, Ade Widiyanti

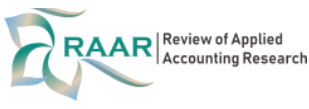

Affiliation:

Accounting Department,

Universitas Lampung, Indonesia

*Correspondence:

rosanovilia@gmail.com

Article Process:

Submitted:

January 26, 2022

Reviewed:

February 1, 2022

Revised:

February 5, 2022

Accepted:

February 10, 2022

Published:

February 15, 2022

\section{Citation:}

Novilia. Rosa, Yuliansyah, Ade Widiyanti. (2022). Reaksi Pasar Modal Terhadap Pandemi Covid-19

Di Indonesia. RAAR: Review of

Applied Accounting Research, 2 (1), 219-231.

Office Address:

Jl. K.H. Ahmad Dahlan, Dukuhwaluh, Kec.

Kembaran, Kabupaten

Banyumas, Jawa Tengah 53182

e-ISSN : 2807-8969

\begin{abstract}
ABSTRAK
Penelitian ini mengkaji perbedaan Abnormal return, Market capitalization, Trading volume activity, dan frekuensi perdagangan untuk mengidentifikasi kandungan informasi mengenai kebijakan yang dilakukan selama pandemi Covid-19 berlangsung di Indonesia yaitu PSBB yang di lakukan di Kota DKI Jakarta. Dalam penelitian ini terdapat dua peristiwa yang diteliti kandungan informasinya yaitu pengumuman pemberlakuan PSBB pertama di Indonesia yang terjadi di Kota DKI Jakarta, dan pengumuman pemberlakuan PSBB tahap kedua, yang juga terjadi di Kota DKI Jakarta. Subsektor hotel, restoran, dan pariwisata diwakili oleh 36 perusahaan yang akan dijadikan contoh dalam penelitian ini. Penelitian berlangsung selama 11 hari, terdiri dari 5 hari menjelang acara, 1 hari selama acara, dan 5 hari setelah acara. Uji nonparametrik Wilcoxon Signed Rank Test digunakan untuk menguji hipotesis dalam penelitian ini. Hasil pengujian hipotesis menunjukkan bahwa Pada saat pemberlakuan PSBB pertama, terdapat perbedaan Abnormal Return dan Kapitalisasi Pasar, namun tidak terdapat perbedaan aktivitas Volume Perdagangan dan Frekuensi Perdagangan. Terdapat perbedaan Abnormal return, Kapitalisasi pasar, Aktivitas volume perdagangan namun tidak terdapat perbedaan frekuensi perdagangan pada pengumuman pemberlakuan PSBB tahap kedua di DKI Jakarta.
\end{abstract}

Kata kunci: PSBB, Abnormal return, Kapitalisasi Pasar, Volume Aktivitas Perdagangan, Frekuensi Perdagangan.

\section{ABSTRACT}

This study examines the differences in abnormal returns, market capitalization, trading volume activity, and trading frequency to identify the information content of policies implemented during the Covid-19 pandemic in Indonesia, namely the PSBB carried out in the city of DKI Jakarta. In this study, there were two events that examined the information content, namely the announcement of the implementation of the first PSBB in Indonesia which occurred in the City of DKI Jakarta, and the announcement of the implementation of the second phase of PSBB, which also occurred in the City of DKI Jakarta. The hotel, restaurant, and tourism sub-sectors are represented by 36 companies that will be used as examples in this study. The study lasted for 11 days, consisting of 5 days before the event, 1 day during the event, and 5 days after the event. The nonparametric Wilcoxon Signed Rank Test was used to test the hypothesis in this study. The results of hypothesis testing indicate that when the first PSBB was implemented, there were differences in Abnormal Return and Market Capitalization, but there were no differences in Trading Volume and Trading Frequency activities. 
There are differences in abnormal returns, market capitalization, trading volume activities but there is no

difference in trading frequency in the announcement of the second phase of PSBB in DKI Jakarta.

Keywords: PSBB, Abnormal return, Market Capitalization, Trading Activity Volume, Trading Frequency.

\section{PENDAHULUAN}

Pasar modal ialah perkaitan para pihak yang mempunyai keunggulan pembiayaan dana serta pihak yang memerlukan dana melalui metode jual beli sekuritas (Tandelilin, 2010:13). Pasar modal menjadi instrumen keuangan yang memiliki peran vital dalam mendorong perkembangan ekonomi negara. Terdapat dua kegunaan dari pasar modal yang pertama ialah untuk penanaman usaha ataupun media untuk menambahkan dana yang dimiliki oleh pemodal atau investor dan yang kedua yaitu sarana untuk masyarakat umum berinvestasi (Husnan, 2009:54).

Tujuan seorang investor dalam berinvestasi dipasar modal yaitu supaya mendapatkan pengembalian atau return atas dana dari investasi. Untuk mendapatkan pengembalian maka harus dilakukan penilaian terhadap perusahaan yang akan diberikan dana oleh pihak investor, dan harus memperhatikan beberapa hal dapat berpengaruh pada kondisi pasar modal. Faktor internal yang dapat mendorong kondisi pasar modal antara lain hasil operasi perusahaan, catatan keuangan, dan kiat perusahaan. Faktor eksternal terdiri dari kemapanan politik, inflasi, dan kondisi ekonomi yang tidak pasti. Suatu kejadian pada umumnya memiliki informasi yang bisa saja mempengaruhi keadaan pasar modal. Informasi dari peristiwa tersebut membantu investor dalam membuat keputusan investasi sehingga harus dicatat dengan baik oleh investor (Putri, 2020).

Contoh peristiwa yang mampu mempengaruhi kondisi pasar modal di Indonesia adalah kejadian munculnya pandemi Covid-19 yang pertama kali terjadi pada Kota Wuhan di Negara China pada Desember 2019. Munculnya Corona Virus Disease (Covid-19) ini kemudian menjadi wabah yang mendunia, dan Indonesia adalah satu dari sekian negara yang tertimpa pandemi Covid-19. Tersebarnya virus Covid-19 pertama kali ada di Indonesia pada 2 Maret 2020, Presiden Republik Indonesia yakni Jokowi mengumumkan dalam pidatonya terkait hal tersebut di Istana Kepresidenan, Jakarta (Detik Finance, 2020). Meluasnya penyebaran Covid-19 ini akhirnya membuat pemerintah melakukan beberapa kebijakan untuk meminimalisir penyebaran dari virus Covid-19 seperti penerapan PSBB dan kebijakan lainnya. PSBB sendiri bertujuan untuk membatasi kegiatan tertentu warga sekitar yang diduga terinfeksi Covid-19 agar mencegah cela penyebaran (Kompas, 2020).

PSBB diterapkan pertama kali di Kota DKI Jakarta pada tanggal 10 April 2020 kemudian diikuti oleh kota lainnya, hal tersebut diumukan pada Selasa malam, 7 April 2020, oleh Anies Baswedan selaku Gubernur DKI Jakarta (CNN Indonesia, 2020). Sesuai dengan ketentuan yang berlaku, penerapan PSBB di Kota DKI Jakarta berlaku selama dua minggu dan kebijakan tersebut dapat mengalami perperpanjangan ataupun diakhiri, hal tersebut bergantung kepada situasi dan kondisi dari penyebaran virus Covid-19 di Indonesia. Penerapan peraturan PSBB yang dilakukan pertama kali di Jakarta mengalami perpanjangan sebanyak dua kali pada tanggal 24 April sampai 22 Mei 2020 kemudian pada 24 Mei sampai 4 Juni 2020 (CNN Indonesia, 2020).

RAAR Penerapan PSBB di Jakarta kembali dilakukan secara ketat pada bulan september dikarenakan kasus Covid-19 yang kembali mengalami kenaikan secara drastis. Kebijakan penerapan PSBB tahap kedua diterapkan pada tanggal 14 September 2020, hal itu disampaikan pada hari Rabu malam tanggal 9 September 2020 oleh Anies Baswedan selaku Gubernur DKI Jakarta (Tirto, 2020). 
Adanya penerapan PSBB dan beberapa kebijakan lain seperti penutupan sementara tempat wisata dan perhotelan, larangan untuk makan di tempat pada restoran-restoran yang beroperasi membuat sektor hotel, restoran dan pariwisata mengalami penurunan dari beberapa aspek, seperti penurunan jumlah kunjungan wisatawan mancanegara yang berdampak terhadap penurunan devisa sektor pariwisata dan penurunan PDB dari sektor pariwisata. Keuangan dan harga saham perusahaan sub sektor hotel, pariwisata dan restoran mengalami penurunan akibat menurunya kunjungan wisatawan yang diakibatkan oleh penerapan PSBB pertama dan PSBB kedua di Kota DKI Jakarta.

Penelitian ini menggunakan analisis studi kasus untuk menguji apakah terdapat informasi yang terkandungan di dalam sebuah peristiwa yang sedang berlangsung. Apabila peristiwa tersebut memiliki suatu informasi, maka diharapkan informasi tersebut dapat bereaksi dengan pasar modal. Variabel abnormal return, market capitalization, trading volume activity dan frekuensi perdagangan menjadi ukuran reaksi pasar modal dalam penelitian ini, pemilihan keempat variabel tersebut untuk melihat apakah informasi tersebut berdampak pada peristiwa yang sedang berlangsung. Peristiwa yang diuji dalam penelitian ini untuk dilihat kandungan informasinya adalah peristiwa pengumuman penerapan PSBB yang pertama di DKI Jakarta, dan pengumuman penerapan PSBB kedua di DKI Jakarta.

\section{TINJAUAN PUSTAKA}

\section{Teori Efisiensi Pasar}

Efiensiensi pasar merupakan bagaimana semua informasi yang beredar dapat mempengaruhi harga pasar. Pergantian harga saham menurut teori ini tidak bergantung kepada harga saham di masa lalu, namun terjadi karena adanya berbagai data yang ada dan muncul dipasar.

\section{Pasar Modal}

Pasar modal ialah perkaitan berbagai pihak yang mempunyai keunggulan biaya serta pihak atau kalangan yang membutuhkan dana melalui metode jual beli sekuritas (Tandelilin, 2010:13). Pasar modal sebagai instrumen keuangan memiliki peran vital dalam mendorong perkembangan ekonomi negara, hal tersebut menjadikan perusahaan mendapatkan suntikan dana karena pasar modal menjadi sumber pendanaan bagi perusahaan tersebut. Selain menjadi sumber pembiayaan dalam dunia bisnis, pasar modal dapat dijadikan media bagi masyarakat yang ingin menanamkan modal baik itu dengan modal yang besar maupun kecil.

\section{Abnormal return}

Perbedaan pengembalian yang diterima (actual return) dengan pengembalian sesuai yang diinginkan (expected return) merupakan istilah abnormal return Jogiyanto (2013:609). Pengembalian yang diterima (actual return) ialah return yang berlangsung dalam hari ke-t, pengembalian tersebut adalah perbedaan antara biaya sekarang relatif dengan biaya saham sebelumnya. Semantara itu, harapan pengembalian (expected return) ialah keuntungan atau pengembalian yang diinginkan oleh pihak penanam modal yang akan didapatkannya di kemudian hari atas dana yang telah ditempatkannya. Terdapat tiga model untuk menghitung expected return dalam melakukan perhitungan abnormal return yakni market model, mean adjusted model dan market adjusted model.

\section{Market capitalization}

Kapitalisasi pasar atau market capitalization merupakan kualitas pasar yang berasal dari saham yang diwujudkan suatu emiten (Rahardjo, 2006:41). Secara umum, saham beserta kapitalisasi pasar yang cukup besar merupakan tujuan investasi berkepanjangan bagi investor untuk berinvestasi, karena selain alasan pembagian dividen dan juga eksposur risiko yang cukup rendah, perusahaan memiliki potensi pertumbuhan yang luar biasa (Mufreni \& Amanah, 2015).

\section{RAAR} Vol2.No.1 


\section{Trading volume activity}

39 Trading volume activity (TVA) ialah waktu atau jumlah saham tertentu dimana transaksi telah terjadi di bursa saham, dan menjadi satu dari sekian faktor dalam pergerakan harga saham. Yahya (2008) berpendapat bahwa aktivitas volume atau jumlah perdagangan (trading volume activity) adalah ukuran kenaikan jumlah aktivitas perdagangan saham yang bersangkutan dari apa yang diumumkan perusahaan tersebut pada saat pengumuman. Semakin tinggi tingkat perdagangan saham suatu perusahaan, menunjukkan bahwa saham dari perusahaan itu banyak diinginkan oleh para investor. Tingginya tingkat perdagangan saham membuat harga saham suatu perusahaan menjadi meningkat.

\section{Frekuensi Perdagangan}

Banyaknya transaksi yang terjadi pada suatu periode tertentu merupakan definisi frekuensi perdagangan menurut Ningsih (2012). Sedangkan pendapat Silviyani et al., (2014) saham yang frekuensi perdagangannya tinggi dipengaruhi oleh tingkat keaktifan transaksi saham. Hal tersebut terjadi karena tingginya minat dari para penanam modal untuk menanamkan modalnya pada perusahaan tersebut. Tingkat frekuensi saham yang tinggi menandakkan bahwa saham perusahaan tersebut diinginkan atau diinginkan oleh para penanam modal atau investor.

\section{PENGEMBANGAN HIPOTESIS}

\section{Terdapat Perbedaan Abnormal return pada Peristiwa PSBB Jakarta}

Fama (1970) mengemukakan dalam teori pasar efisien, perubahan harga saham menjadi Salah satu respon dari informasi yang terdapat di dalam suatu peristiwa. Pengumuman PSBB pertama di Indonesia yang terjadi di Kota DKI Jakarta menjadi sinyal bagi pemerintah kepada pelaku pasar modal. PSBB yang dilakukan sebagai salah satu bentuk kebijakan yang dibuat pemerintah untuk meminimalkan resiko penyebaran dari virus Covid-19 di Indonesia. Namun kebijakan tersebut membuat beberapa sektor mengalami penurunan karena terbatasnya ruang gerak masyarakat sehingga membuat beberapa sektor mengalami dampak negatif, salah satu sektor yang mengalami dampak yaitu sektor hotel, restoran dan pariwisata. Turunya abnormal return disebabkan karena sentimen pesimistis penanam modal akibat dari adanya pengumuman penerapan PSBB pertama di Kota DKI Jakarta.

Alam et al., (2020) memiliki hasil penelitian yang menunjukkan bahwa pasar memiliki tanggapan atau respon yang baik terhadap variabel AAR (average abnormal return) selama lockdown dilakukan di negara India.

Berdasarkan pembahasan diatas, maka penelitian ini memiliki hipotesis yaitu:

H1a : Diperoleh perbedaan abnormal return sebelum dan sesudah diterapkannya PSBB di Kota DKI Jakarta tahap pertama diumumkan.

Untuk menekan kasus Covid-19 di Indonesia penerapan PSBB yang lebih ketat dilakukan kembali di beberapa Kota hingga Provinsi. Jakarta kembali menjadi kota pertama yang menerapkan PSBB tahap kedua, pengumuman PSBB tahap kedua di Jakarta terjadi pada tanggal 9 September malam, penerapan PSBB Jakarta dilakukan pada tanggal 14 September. Satu hari setelah pengumuman PSBB tahap kedua di Jakarta tepatnya tanggal 10 September IHSG mengalami penurunan yang sangat drastis hingga BEI harus melakukan trading halt.Hal tersebut membuktikan bahwa pengumuman penerapan PSBB tahap kedua memberikan sentimen negatif terhadap investor dan pasar modal.

Hasil penelitian dari Anh \& Gan (2020) membuktikan bahwa ketika terjadi lockdown di RAAR terdapat pengaruh yang positif kepada kinerja saham perusahaan di seluruh sektor bisnis negara Vol.2 No.1 Vietnam. 
Berdasarkan pembahasan diatas, maka penelitian ini memiliki hipotesis yaitu:

H1b : Diperoleh perbedaan abnormal return sebelum dan sesudah diterapkannya PSBB di Kota DKI Jakarta tahap kedua diumumkan.

Terdapat Perbedaan Market capitalization pada Peristiwa PSBB Jakarta

Beberapa investor menggunakan kapitalisasi pasar sebagai salah satu indikator dalam mengambil keputusan untuk memilih menginvestasikan dananya ke suatu perusahaan. Kapitalisasi pasar dibagi menjadi tiga yaitu kapitalisasi kecil, sedang dan besar. Diminatinya suatu saham oleh para investor disebabkan karena suatu perusahaan mempunyai kapitalisasi pasar yang semakin besar.

Dengan adanya pengumuman pertama PSBB di Indonesia membuat banyak perusahaan sub sektor restoran, pariwisata dan hotel mengalami penurunan harga saham karena kebijakan tersebut membuat masyarakat menghabiskan banyak waktunya di rumah sehingga menjadikan sektor pariwisata mengalami penurunan wisatawan, yang akhirnya membuat sektor hotel, restoran dan pariwisata mengalami penurunan.

Hasil penelitian dari Anh \& Gan (2020) menunjukkan hasil perbedaan variabel kapitalisasi pasar sebelum dan sesudah kejadian lockdown yang dilakukan di Vietnam.

Berdasarkan pembahasan diatas, maka penelitian ini memiliki hipotesis yaitu:

H2a : Diperoleh perbedaan terhadap market capitalization sebelum dan sesudah diumumkannya penerapan PSBB pertama kali di Kota DKI Jakarta.

Pengumuman PSBB tahap kedua di Jakarta memberikan sentimen negatif terhadap para investor dan pasar modal. Sehari setelah adanya pengumuman PSBB tahap kedua IHSG anjlok hingga 5 persen dan akhirnya terjadi trading halt (penutupan sementara). Selama periode 7-11 September, pasar modal mayoritas ditutup pada zona merah. Nilai kapitalisasi pasar bursa anjlok 4,17\% menjadi Rp 5.827,724 triliun yang sebelumnya berada di Rp 6.081,396 triliun (Sindonews, 2020). Pada saat harga saham mengalami penurunan, maka biasanya kapitalisasi pasar yang beredar akan mengalami penurunan, dan berlaku sebaliknya

Hasil penelitian dari Anh \& Gan (2020) menunjukkan hasil yang didapatkan pada perbedaan variabel kapitalisasi pasar sebelum dan sesudah kejadian lockdown yang dilakukan di Vietnam.

Berdasarkan pembahasan diatas, maka penelitian ini memiliki hipotesis yaitu:

H2b : Diperoleh perbedaan pada market capitalization sebelum dan sesudah kota DKI Jakarta mengumumkan penerapan tahapan kedua PSBB.

\section{Terdapat Perbedaan Trading Volume Activity pada Peristiwa PSBB Jakarta}

Salah satu hal mengenai kabar pokok yang harus diketahui oleh para penanam modal adalah informasi jumlah perdagangan dalam pasar modal, volume atau jumlah perdagangan saham juga dapat dipakai sebagai tolak ukur dalam meninjau seberapa besar respon pasar terhadap salah satu informasi. Likuiditas saham dapat meningkat karena tingginya jumlah perdagangan.

Indikasi adanya reaksi pasar ditunjukkan ketika terjadi perubahan jumlah perdagangan saham saat kabar tersebut diumumkan dan semua pelaku pasar telah menerima kabar tersebut (Zainuddin \& Hartono, 1999).

Ketidakstabilan perekonomian akibat penerapan PSBB mengakibatkan pengaruh yang penting kepada pencapaian perusahaan serta berdampak terhadap pasar modal. Pengumuman PSBB dapat mengandung informasi atau kabar yang dapat memberikan pengaruh untuk penanam modal dalam mengambil keputusan.

Berdasarkan pembahasan diatas, maka hipotesis dari penelitian ini adalah:

RAAR Vol2.No.1 
H3a : Terdapat perbedaan terhadap trading volume activity sebelum dan sesudah pengumuman penerapan PSBB pertama di Kota DKI Jakarta.

\section{Terdapat Perbedaan Trading Volume Activity pada Peristiwa PSBB Jakarta}

Jumlah perdagangan saham memiliki peran yang vital bagi para penanam modal atau investor, hal tersebut dikarenakan jumlah perdagangan saham yang digambarkan dengan keadaan saham yang diperjualbelikan di pasar modal (Wahyu dan Andi, 2005).

Pengumuman PSBB tahap kedua menjadi sentimen negatif bagi pasar modal di Indonesia. akibat dari pengumuman PSBB tahap kedua membuat volume perdagangan mengalami penurunan. Penurunan volume perdagangan saham yang terjadi dikarenakan adanya aksi penjualan yang cukup signifikan yang dilakukan oleh pihak investor untuk meminimalisir kerugian yang diterima karena harga saham yang mengalami penurunan selama periode tersebut.

Berdasarkan pembahasan diatas, maka penelitian ini memiliki hipotesis yaitu:

H3b : Terdapat perbedaan terhadap trading volume activity sebelum dan sesudah pengumuman penerapan PSBB tahap kedua di Kota DKI Jakarta.

\section{Terdapat Perbedaan Frekuensi Perdagangan pada Peristiwa PSBB Jakarta}

Suatu peristiwa yang terjadi dapat mempengaruhi frekuensi perdagangan perusahaan. Pasar modal sangat peka dengan isu dan peristiwa atau kejadian yang paruh terjadi. Salah satu kejadian yang terjadi untuk mengurangi menyebarnya virus tersebut di Indonesia yaitu pembatasan sosial berskala besar atau PSBB. Peristiwa ini telah memberikan pengaruh terhadap pasar modal di Indonesia.

Pengumuman PSBB pertama di Indonesia yang dilakukan di Kota DKI Jakarta menjadi salah satu bentuk sinyal dari pemerintah bagi para investor. Penerapan PSBB yang diberlakukan memiliki tujuan yakni menurunkan penyebaran dari virus Covid-19 yang ada di Indonesia sehingga menjadikan perekonomian di Indonesia menjadi tidak stabil bahkan mengalami kontraksi ditengah pemberlakuan PSBB. Ketidakstabilan perekonomian akibat penerapan PSBB menyebabkan pengaruh yang penting kepada kinerja perusahaan serta berpengaruh terhadap pasar modal.

Berdasarkan bahasan diatas, maka hipotesis dari penelitian ini adalah:

H4a : Adanya perbedaan terhadap frekuensi perdagangan sebelum dan sesudah diumumkannya penerapan PSBB yang pertama di Kota DKI Jakarta.

Menurut Ang (2012) peningkatan permintaan saham secara tidak langsung akan meningkatan frekuensi perdagangan. Sedangkan penelitian yang telah dilakukan oleh Yadav et al., (1999) menyatakan bahwa ditemukan hubungan yang positif antara frekuensi perdagangan atas return saham. Suatu peristiwa dapat mempengaruhi pasar modal di Indonesia. Faktor tersebut disebabkan pasar modal sangat rentan terhadap segala isu yang paruh terjadi. Pengumuman PSBB menjadi salah satu kejadian yang berpengaruh terhadap pasar modal Indonesia.

Pengumuman PSBB tahap kedua menjadi sentimen negatif bagi pasar modal di Indonesia. IHSG mengalami penurunan yang sangat drastis bahkan hingga dilakukan trading halt (penutupan sementara) selama 30 menit dikarenakan IHSG semakin menurun hingga mencapai 5 persen.

Berdasarkan pembahasan diatas, maka penelitian ini memiliki hipotesis yaitu:

RAAR H4b : Diperoleh perbedaan terhadap frekuensi perdagangan sebelum dan sesudah adanya Vol.2 No.1 pengumuman penerapan PSBB tahap kedua di Kota DKI Jakarta.

\section{METODE PENELITIAN}

\section{Populasi dan Sampel}


Populasi yang penulis gunakan pada penelitian ini yaitu perusahaan yang tercatat dalam sub sektor hotel, restoran dan pariwisata yang terdaftar pada Bursa Efek Indonesia (BEI) selama periode penelitian 2020. Metode purposive sampling digunakan dalam penelitian ini yang merupakan cara kerja untuk penentuan sampel atau percontohan yang memenuhi kriteria tertentu. Dengan adanya kriteria sampel pada penelitian ini, maka sampel yang akan digunakan untuk penelitian yang akan dilakukan adalah sebanyak 36 perusahaan hal tersebut dikarenakan pada saat perriode penelitian ada satu perusahaan yang mengalami suspensi sehingga saham perusahaan tersebut tidak aktif diperdagangkan selama periode jendela.

\section{Jenis dan Sumber Data}

Data sekunder yang mempunyai sifat historis, merupakan jenis data yang digunakan pada penelitian ini. Data yang peneliti gunakan pada penelitian ini merupakan data harga saham harian emiten yang tercatat di Bursa Efek Indonesia (BEI), data Indeks Harga Saham Gabungan (IHSG) harian perusahaan, data volume perdagangan harian, volume transaksi perdagangan harian dan data nilai saham harian yang diperdagangkan. Sumber Penelitian ini memperoleh data dari situs resmi Bursa Efek Indonesia yaitu www.idx.co.id pada bagian data pasar saham untuk mendapatkan data harga penutupan saham harian, volume perdagangan, dan data frekuensi perdagangan harian dan www.yahoofinance.com

\section{Pengertian Operasional Variabel}

\section{Abnormal return}

Abnormal return adalah perbandingan antara tingkat profit yang sesungguhnya (actual return) dengan tingkat profitabilitas yang diharapkan (expected return) (Jogiyanto, 2013). Model market-adjusted model dipakai dalam penelitian ini untuk menghitung expected return. Menurut Jogiyanto (2013:610) rumus yang dipakai dalam menghitung abnormal return yaitu:

$$
\text { ARi.t }=\text { Ri.t }-\mathrm{E}(\text { Ri.t })
$$

Keterangan:

ARi.t : Abnormal return saham ke-i pada hari ke $\mathrm{t}$

Ri.t : Actual return saham i pada hari ke $\mathrm{t}$

$\mathrm{E}(\mathrm{Ri} . \mathrm{t})$ : Expected return pasar pada hari ke t

\section{Market capitalization}

Market capitalization merupakan nilai pasar dari suatu emiten yang menerbitkan saham (Rahardjo, 2006:41). Dalam buku Ang (1997) rumus dari kapitalisasi pasar yakni sebagai berikut:

$$
\mathrm{Vs}=\mathrm{Ps} \mathrm{X} \text { Ss }
$$

Keterangan :

$$
\begin{array}{ll}
\text { Vs } & \text { : Kapitalisasi pasar } \\
\text { Ps } & \text { : Harga Pasar saham } \\
\text { Ss } & \text { : Jumlah saham yang diterbitkan }
\end{array}
$$

\section{Trading volume activity}

Cara menghitung trading volume activity adalah dengan membagi antara volume saham yang diperdagangkan dengan jumlah saham beredar pada waktu tertentu. Menurut (Husnan, 2009:63) trading volume activity dirumuskan sebagai berikut: 


\section{Frekuensi Perdagangan}

Frekuensi dapat menggambarkan jumlah transaksi saham suatu perusahaan dalam kurun waktu tertentu. Dalam penelitian Nasir \& Mirza (2010) frekuensi perdagangan dirumuskan sebagai berikut :

$$
\text { Frekuensi perdagangan saham }=\frac{\text { Jumlah Frekuensi Saham }}{\text { Hari Pengamatan }}
$$

\section{Metode Analisis Data}

\section{Uji Normalitas}

Normal atau tidaknya penyaluran data dapat diketahui dengan melakukan uji normalitas (Ghozali, 2013). Pengujian normalitas One-Sample Kolmogorov-Smirnov Test digunakan dalam penelitian ini dengan membandingkan asymptotic significance $\alpha=0,05$. Asas pengambilan keputusan tersebut adalah dikatakan terdistribusi normalnya suatu data apabila tingkat signifikansi atau nilai asymptotic significance-nya $>0,05(5 \%)$.

\section{Pengujian Hipotesis}

Uji hipotesis adalah suatu metode langkah atau tahapan proses yang di didasarkan contoh sampel dan teori probabilitas untuk memutuskan apakah hipotesis merupakan suatu hal yang logis dan dapat dibuktikan kebenarannya Widarjono (2015). Pengujian hipotesis pada penelitian ini dilakukan dengan memakai salah satu dari dua pengujian hipotesis yang pertama yaitu paired sample t-test yang akan dipakai jika data yang telah di uji normalitas terdistribusi normal dan pengujian hipotesis lainnya yaitu uji wilcoxon signed rank test yang akan digunakan jika data yang telah di uji normalitas tidak terdistribusi dengan normal. Dasar pengambilan keputusan dalam uji paired sample t-test dan wilcoxon signed rank test yakni sebagai berikut :

- Jika nilai signifikansi atau $\alpha<0,05$ maka hipotesis diterima.

- Jika nilai signifikansi atau $\alpha>0,05$ maka hipotesis tidak diterima.

\section{HASIL DAN PEMBAHASAN}

\section{Uji Normalitas}

Tabel 1. Uji Normalitas Pengumuman PSBB Pertama di DKI Jakarta

\begin{tabular}{|l|r|r|r|r|r|r|r|r|}
\hline \multicolumn{7}{|c|}{ One-Sample Kolmogorov-Smirnov Test Pengumuman PSBB Pertama di DKI Jakarta } \\
\hline & $\begin{array}{c}\text { AAR } \\
\text { SEBEL } \\
\text { UM }\end{array}$ & $\begin{array}{c}\text { AAR } \\
\text { SESUD } \\
\text { AH }\end{array}$ & $\begin{array}{c}\text { AMC } \\
\text { SEBEL } \\
\text { UM }\end{array}$ & $\begin{array}{c}\text { AMC } \\
\text { SESUD } \\
\text { AH }\end{array}$ & $\begin{array}{c}\text { ATVA } \\
\text { SEBEL } \\
\text { UM }\end{array}$ & $\begin{array}{c}\text { ATVA } \\
\text { SESUD } \\
\text { AH }\end{array}$ & $\begin{array}{c}\text { AFP } \\
\text { SEBEL } \\
\text { UM }\end{array}$ & $\begin{array}{c}\text { AFP } \\
\text { SESUD } \\
\text { AH }\end{array}$ \\
\hline N & 36 & 36 & 36 & 36 & 36 & 36 & 36 & 36 \\
\hline $\begin{array}{l}\text { Asymp. Sig. } \\
\text { (2-tailed) }\end{array}$ &, 000 &, 025 &, 000 &, 000 &, 000 &, 000 &, 000 &, 000 \\
\hline
\end{tabular}

Sumber: Data Sekunder diolah, 2021

Tabel 2. Uji Normalitas Pengumuman PSBB Kedua di DKI Jakarta One-Sample Kolmogorov-Smirnov Test Pengumuman PSBB Kedua di DKI Jakarta 


\begin{tabular}{|l|r|r|r|r|r|r|r|r|}
\hline & $\begin{array}{c}\text { AAR } \\
\text { SEBEL } \\
\text { UM }\end{array}$ & $\begin{array}{c}\text { AAR } \\
\text { SESUD } \\
\text { AH }\end{array}$ & $\begin{array}{c}\text { AMC } \\
\text { SEBEL } \\
\text { UM }\end{array}$ & $\begin{array}{c}\text { AMC } \\
\text { SESUD } \\
\text { AH }\end{array}$ & $\begin{array}{c}\text { ATVA } \\
\text { SEBEL } \\
\text { UM }\end{array}$ & $\begin{array}{c}\text { ATVA } \\
\text { SESUD } \\
\text { AH }\end{array}$ & $\begin{array}{c}\text { AFP } \\
\text { SEBEL } \\
\text { UM }\end{array}$ & $\begin{array}{c}\text { AFP } \\
\text { SESUD } \\
\text { AH }\end{array}$ \\
\hline $\mathrm{N}$ & 36 & 36 & 36 & 36 & 36 & 36 & 36 & 36 \\
\hline $\begin{array}{l}\text { Asymp. Sig. } \\
\text { (2-tailed) }\end{array}$ &, 001 &, 000 &, 000 &, 000 &, 000 &, 000 &, 000 &, 000 \\
\hline
\end{tabular}

\section{Sumber: Data Sekunder diolah, 2021}

Digunakannya one sample kolmogrov-smirnov menunjukkan perolehan dalam pengujian normalitas, bahwa semua variabel berdistribusi tidak normal pada saat sebelum terjadinya dan sesudah kasus Covid-19 pertama kali di Indonesia, penerapan PSBB pertama di Indonesia yang terjadi di Kota Jakarta, dan penerapan PSBB kedua di Indonesia yang terjadi di Kota Jakarta hal tersebut bisa ditinjau dari nilai Asymp. Sig. yang berada dibawah 0,05. Atas hasil uji tersebut pengujian hipotesis menggunakan uji wilcoxon signed rank test.

Tabel 3. Hasil Uji Wilcoxon Variabel Abnormal return pada Peristiwa Pandemi Covid-19 di Indonesia

\begin{tabular}{|l|r|l|c|}
\hline $\begin{array}{l}\text { Pengumuman } \\
\text { PSBB Pertama } \\
\text { di Jakarta }\end{array}$ & $\begin{array}{c}\text { AAR } \\
\text { SESUDAH } \\
-\end{array}$ & $\begin{array}{l}\text { Pengumuman } \\
\text { PSBB Kedua di } \\
\text { JakBarta }\end{array}$ & $\begin{array}{c}\text { AAR } \\
\text { SESUDAH } \\
- \\
\text { SEBELUM }\end{array}$ \\
\hline Z & $-3,353^{\mathrm{b}}$ & $\mathrm{Z}$ & $-4,477^{\mathrm{b}}$ \\
$\begin{array}{l}\text { Asymp. Sig. (2- } \\
\text { tailed) }\end{array}$ &, 001 & $\begin{array}{l}\text { Asymp. Sig. (2- } \\
\text { tailed) }\end{array}$ &, 000 \\
\hline
\end{tabular}

\section{Sumber: Data Sekunder diolah, 2021}

\section{Abnormal return dan Pandemi Covid-19 di Indonesia}

Dari pengujian anggapan dasar atau hipotesis dengan memakai wilcoxon signed rank test untuk hipotesis 1a didapat hasil nilai signifikansi variabel abnormal return sebelum dan sesudah pengumuman penerapan PSBB pertama di Indonesia yang terjadi di kota Jakarta sebesar 0,001 angka tersebut lebih kecil dari 0,05 atau 0,001 <0,05. Maka bisa disimpulkan bahwa diperoleh perbedaan abnormal return antara sebelum dan sesudah diumumkannya penerapan PSBB pertama kali di Indonesia yang terjadi di kota Jakarta. Dengan hasil tersebut maka hipotesis 1a terdukung.

Dari pengujian hipotesis $1 \mathrm{~b}$ diperoleh hasil nilai signifikansi variabel abnormal return sebelum dan sesudah diumumkannya penerapan PSBB tahap kedua yang terjadi di kota Jakarta sebesar 0,000 angka itu lebih kecil dari 0,05 atau $0,000<0,05$. Maka dapat disimpulkan bahwa didapati perbedaan abnormal return antara sebelum dan sesudah diumumkannya penerapan PSBB tahap kedua yang terjadi di kota Jakarta.

Tabel 4. Hasil Uji Wilcoxon Variabel Market capitalization pada Peristiwa Pandemi Covid-19 di Indonesia

\begin{tabular}{|l|r|l|c|}
\hline $\begin{array}{l}\text { Pengumuman } \\
\text { PSBB Pertama } \\
\text { di Jakarta }\end{array}$ & $\begin{array}{c}\text { AMC } \\
\text { SESUDAH } \\
-\end{array}$ & $\begin{array}{l}\text { Pengumuman } \\
\text { PSBB Kedua di } \\
\text { Jakarta }\end{array}$ & $\begin{array}{c}\text { AMC } \\
\text { SESUDAH } \\
- \\
\text { SEBELUM }\end{array}$ \\
\hline Z & $-2,561^{\mathrm{b}}$ & $\mathrm{Z}$ & $-2,112^{\mathrm{b}}$ \\
$\begin{array}{l}\text { Asymp. Sig. (2- } \\
\text { tailed) }\end{array}$ &, 015 & $\begin{array}{l}\text { Asymp. Sig. (2- } \\
\text { tailed) }\end{array}$ &, 035 \\
\hline
\end{tabular}

Sumber: Data Sekunder diolah, 2021 


\section{Market capitalization dan Pandemi Covid-19 di Indonesia}

Dari pengujian hipotesis 2a diperoleh hasil nilai signifikansi variabel market capitalization sebelum dan sesudah diumumkannya penerapan PSBB pertama di Kota DKI Jakarta sebesar 0,015 angka tersebut lebih kecil dari 0,05 atau 0,015 < 0,05. Maka dapat diambil kesimpulan bahwa adanya perbedaan market capitalization antara sebelum dan sesudah pengumuman penerapan PSBB pertama di Kota DKI Jakarta. Dengan hasil tersebut maka hipotesis 2a terdukung.

Dari pengujian hipotesis $2 \mathrm{~b}$ diperoleh hasil nilai signifikansi variabel market capitalization sebelum dan sesudah diumumkannya penerapan PSBB tahap kedua di Kota DKI Jakarta sebesar 0,035 angka tersebut lebih sedikit dari 0,05 atau $0,035<0,05$. Maka dapat diambil kesimpulan bahwa ada perbedaan market capitalization. Dengan hasil tersebut maka hipotesis $2 \mathrm{~b}$ terdukung.

Tabel 5. Hasil Uji Wilcoxon Variabel Trading volume activity pada Peristiwa Pandemi Covid19 di Indonesia

\begin{tabular}{|c|c|c|c|}
\hline $\begin{array}{l}\text { Pengumuman } \\
\text { PSBB } \\
\text { Pertama di } \\
\text { Jakarta }\end{array}$ & $\begin{array}{c}\text { ATVA } \\
\text { SESUDAH } \\
- \\
\text { SEBELUM }\end{array}$ & $\begin{array}{l}\text { Pengumuman } \\
\text { PSBB Kedua } \\
\text { di Jakarta }\end{array}$ & $\begin{array}{c}\text { ATVA } \\
\text { SESUDAH } \\
- \\
\text { SEBELUM }\end{array}$ \\
\hline $\mathrm{Z}$ &,$- 333^{\mathrm{b}}$ & Z & $-2,132^{b}$ \\
\hline $\begin{array}{l}\text { Asymp. Sig. } \\
\text { (2-tailed) }\end{array}$ & ,739, & $\begin{array}{l}\text { Asymp. Sig. } \\
\text { (2-tailed) }\end{array}$ & ,033 \\
\hline
\end{tabular}

Sumber: Data Sekunder diolah, 2021

\section{Trading volume activity dan Pandemi Covid-19 di Indonesia}

Dari pengujian hipotesis 3a diperoleh hasil nilai signifikansi variabel trading volume activity sebelum dan sesudah pengumuman penerapan PSBB pertama di Indonesia sebesar 0,739 angka tersebut lebih besar dari 0,05 atau 0,739>0,05. sehingga bisa diambil kesimpulan bahwa ditemukan perbedaan trading volume activity antara sebelum dan sesudah diumumkannya penerapan PSBB pertama di Indonesia. Dengan hasil tersebut maka hipotesis 3a terdukung.

Dari pengujian hipotesis $3 \mathrm{~b}$ diperoleh hasil nilai signifikansi variabel trading volume activity sebelum dan sesudah pengumuman penerapan PSBB tahap kedua di Kota DKI Jakarta sebesar 0,033 angka tersebut lebih kecil dari 0,05 atau $0,33<0,05$. Maka dapat disimpulkan bahwa terdapat perbedaan trading volume activity antara sebelum dan sesudah pengumuman penerapan PSBB tahap kedua di Kota DKI Jakarta. Dengan hasil tersebut maka hipotesis $3 b$ terdukung.

Tabel 6. Hasil Uji Wilcoxon Variabel Frekuensi Perdagangan pada Peristiwa Pandemi Covid19 di Indonesia

\begin{tabular}{|c|c|c|c|}
\hline $\begin{array}{l}\text { Pengumuman } \\
\text { PSBB } \\
\text { Pertama di } \\
\text { Jakarta }\end{array}$ & $\begin{array}{c}\text { AFP } \\
\text { SESUDAH } \\
- \\
\text { SEBELUM }\end{array}$ & $\begin{array}{l}\text { Pengumuman } \\
\text { PSBB Kedua } \\
\text { di Jakarta }\end{array}$ & $\begin{array}{c}\text { AFP } \\
\text { SESUDAH } \\
- \\
\text { SEBELUM }\end{array}$ \\
\hline $\mathrm{Z}$ &,$- 767^{b}$ & $\mathrm{Z}$ &,$- 952^{\mathrm{b}}$ \\
\hline $\begin{array}{l}\text { Asymp. Sig. } \\
\text { (2-tailed) }\end{array}$ & ,443 & $\begin{array}{l}\text { Asymp. Sig. } \\
\text { (2-tailed) }\end{array}$ & ,341 \\
\hline
\end{tabular}

Sumber: Data Sekunder diolah, 2021

Frekuensi Perdagangan dan Pandemi Covid-19 di Indonesia

Dari pengujian hipotesis 4 a diperoleh hasil nilai signifikansi variabel frekuensi perdagangan sebelum dan sesudah diumumkannya penerapan PSBB yang pertama di Indonesia sebesar 0,443 
angka tersebut lebih tinggi dari 0,05 atau 0,443>0,05. Maka bisa disimpulkan bahwa diperoleh perbedaan frekuensi perdagangan antara sebelum dan sesudah diumumkannya penerapan PSBB yang pertama di Indonesia. Dengan hasil tersebut maka hipotesis 4a terdukung.

Dari pengujian hipotesis $4 \mathrm{~b}$ diperoleh hasil nilai signifikansi variabel frekuensi perdagangan sebelum dan sesudah diumumkannya penerapan PSBB tahap dua di Kota DKI Jakarta sebesar 0,576 angka tersebut lebih tinggi dari 0,05 atau 0,576 > 0,05. Maka kesimpulan dari penelitian ini adalah terdapat perbedaan frekuensi perdagangan antara sebelum terjdainya peristiwa dan sesudah peristiwa pengumuman penerapan PSBB kedua di Kota DKI Jakarta. Dengan hasil tersebut maka hipotesis $4 \mathrm{~b}$ terdukung.

\section{KESIMPULAN}

Berdasarkan pengujian yang telah dilakukan mengunakan uji non parametrik maka diperoleh hasil sebagai berikut :

1. Tidak adanya perbedaan variabel abnormal return sebelum dan sesudah dan pengumuman penerapan PSBB pertama di Kota DKI Jakarta. Namun terdapat perbedaan pada saat sebelum dan sesudah peristiwa pengumuman penerapan PSBB tahap kedua yang terjadi di Kota DKI Jakarta.

2. Terdapat perbedaan variabel market capitalization sebelum dan sesudah adanya pengumuman penerapan PSBB pertama di Kota DKI Jakarta dan pengumuman penerapan PSBB tahap kedua yang terjadi di Jakarta.

3. Terdapat perbedaan variabel trading volume activity pada peristiwa pengumuman penerapan PSBB tahap kedua yang terjadi di Kota DKI Jakarta. Sedangkan pada pengumuman penerapan PSBB pertama di Kota DKI Jakarta tidak terdapat perbedaan.

4. Tidak terdapat perbedaan pada variabel frekuensi perdagangan pada semua peristiwa yang telah diuji.

\section{SARAN}

Berdasarkan hasil penelitian yang sudah dilakukan, dipdapatkan beberapa saran dari peneliti yakni sebagai berikut:

1. Peneliti menyarankan kepada manajemen untuk memperhatikan beberapa faktor yang kemungkinan berpengaruh pada fluktuasi harga saham suatu perusahaan.

2. Disarankan kepada para investor untuk tidak terlalu cepat pada saat mengambil keputusan ketika suatu peristiwa terjadi, dan tidak terpengaruh dengan isu-isu yang beredar terkait dengan adanya suatu peristiwa.

3. Bagi penelitian selanjutnya dapat menggunakan objek pada sektor lain yang ikut terdampak dengan adanya peristiwa Covid-19 di Indonesia.

\section{KETERBATASAN}

Dalam penelitian ini terdapat beberapa kendala yang dihadapi oleh peneliti yaitu terbatasnya referensi pendukung mengenai peristiwa penerapan PSBB tahap pertama dan kedua terhadap variabel abnormal return, market capitalization, trading volume activity dan frekuensi perdagangan. Keterbatasan lainnya yaitu sektor yang ditelliti dalam penelitian ini hanya satu sub sektor saja yang membuat populasi dari penelitian ini terlalu kecil dan tidak bisa dibandingkan dengan sektor lain yang terdampak pandemi Covid-19. 


\section{REFERENSI}

Agus, W. (2015). Statistika Terapan Dengan Excel \& SPSS. In Statistika Terapan Dengan Excel \& SPSS (Pertama). Badan Penerbit UPP STIM YKPN.

ALAM, M. N., ALAM, M. S., \& CHAVALI, K. (2020). Stock Market Response During COVID-19 Lockdown Period In India: An Event Study. Journal Of Asian Finance, Economics And Business, 7 No 7, 131-137. Https://Doi.Org/10.13106/Jafeb.2020.Vol7.No7.131

Ang, R. (2012). Buku Pintar Pasar Modal Indonesia (The Intelligent Guide To Indonesian Capital Market) (Pertama). Mediasoft Indonesia.

Anh, D. L. T., \& Gan, C. (2020). The Impact Of The COVID-19 Lockdown On Stock Market Performance: Evidence From Vietnam. Journal Of Economic Studies, 48(4), 836-851. Https://Doi.Org/Https://Doi.Org/10.1108/JES-06-2020-0312

CNN Indonesia (2020). Saham Sektor Pariwisata Paling Terpukul Corona Https://Www.Cnnindonesia.Com/Ekonomi/20200327171330-92-487612/Saham-SektorPariwisata-Paling-Terpukul-Corona

Detik Finance (2020). Perjalanan IHSG Sejak RI Positif Virus Corona Https://Finance.Detik.Com/Bursa-Dan-Valas/D-4972595/Perjalanan-Ihsg-Sejak-RiPositif-Virus-Corona

Hindayani, N. (2020). Analisis Reaksi Pasar Saham Atas Peristiwa COVID-19 Di Indonesia. Jurnal Ilmiah MEA (Manajemen, Ekonomi, Dan Akuntansi), 4(3), 1645-1661. Http://Journal.Stiemb.Ac.Id/Index.Php/Mea/Article/View/647

Husnan, S. (2009). Dasar-Dasar Teori Portofolio Dan Analisis Sekuritas (Keempat). UPP AMP YKPN.

Jogiyanto, H. (2013). Teori Portofolio Dan Analisis Investasi (Delapan). BPFE-Yogyakarta.

Kumar, M. P., \& Kumara, N. V. M. (2020). Market Capitalization: Pre And Post COVID-19 Analysiskumar, M. P., \& Kumara, N. V. M. (2020). Market Capitalization: Pre And Post COVID-19 Analysis. August. Https://Doi.Org/Https://Doi.Org/10.1016/J.Matpr.2020.08.493.

Mufreni, A. N., \& Amanah, D. (2015). Pengaruh Kapitalisasi Pasar Dan Likuiditas Saham Terhadap Harga Saham Pada Pt. Astra Internasional Tbk. Jurnal Ekonomi Manajemen, 1(1), 29-35. Http://Jurnal.Unsil.Ac.Id/Index.Php/Jem/Article/View/305/217

Putri, T. N. A. (2020). Reaksi Pasar Modal Indonesia Terhadap Fluktuasi Rupiah Atas Pandemi Covid-19 (Studi Pada Perusahaan Yang Terdaftar Pada LQ45 Di Bursa Efek Indonesia). 19, Jurnal Ilmiah Mahasiswa FEB, 8(2).

Rahardjo, S. (2006). Kiat Membangun Aset Kekayaan. PT. Elex Media Komputindo.

Silviyani, N. L. N. T., Dr. Edy Sujana, SE, Msi, A., \& I MADE PRADANA ADIPUTRA, S.E., S.H., M. S. (2014). Pengaruh Likuiditas Perdagangan Saham Dan Kapitalisasi Pasar Terhadap Return Saham Perusahaan Yang Berada Pada Indeks LQ45 Di Bursa Efek Indonesia Periode Tahun 2009-2013. E-Journal S1 Ak Universitas Pendidikan Ganesha, 2(1).

RAAR Subrata, I. K., \& Werastuti, D. N. S. (2020). Analisis Reaksi Pasar Pada Penetapan Status Darurat Global Ke Level Tertinggi Terkait Virus Corona Oleh WHO ( World Health Organization ) Pada Bursa Efek Indonesia. JIMAT (Jurnal Ilmiah Mahasiswa Akuntansi) Universitas Pendidikan Ganesha, 11(2), 169-177.

Sudiyatno, B., \& Suharmanto, T. (2011). Kinerja Keuangan Konvensional, Economic Value 
Rosa Novilia, Yuliansyah, Ade Widiyanti (Vol. 2, No. 1, February, 2022)

Added, Dan Return Saham. Jurnal Dinamika Manajemen, 2(2), 153-161.

Tandelilin, E. (2010). Portofolio Dan Investasi: Teori Dan Aplikasi (Edisi Pert). Kanisius. 